UDC 504.064: 614.7

DOI: 10.21668/health.risk/2020.1.03.eng

\title{
EFFICIENCY OF HEALTH RISK MITIGATION: COMPLEX ASSESSMENT BASED ON FUZZY SETS THEORY AND APPLIED IN PLANNING ACTIVITIES AIMED AT AMBIENT AIR PROTECTION
}

\author{
N.V. Zaitseva ${ }^{1}$, M.A. Zemlyanova ${ }^{1,2}$, I.V. May ${ }^{1}$, V.B Alekseev ${ }^{1}$, \\ P.V. Trusov ${ }^{2}$, E.V. Khrushcheva ${ }^{1}$, A.A. Savochkina ${ }^{2}$
}

${ }^{1}$ Federal Scientific Center for Medical and Preventive Health Risk Management Technologies, 82 Monastyrskaya Str., Perm, 614045, Russian Federation

${ }^{2}$ Perm National Research Polytechnic University, 29 Komsomolskiy Ave., Perm, 614990, Russian Federation

When industrial objects emitting substantial masses of dust and gas mixtures are located within a settlement or close to its borders, it often results in poorer quality of the environment and damages to population health. Such a situation is typical for many cities in the country; primarily, for those that are included into "Pure air" Federal project, a part of the "Ecology" National project. Negative effects are produced by a set of various substances emitted from various industries. And it is quite often that great numbers of people are exposed to such emissions and as a result multiple and variable responses from their health are registered. Assessment of share contributions made by different emissions sources and each particular substance into aggregated negative responses from human health is a fundamental stage in assessing damages to health that occurred due to them; it is significant for working out an action plan aimed at hazardous impacts mitigation.

Given that, we proposed an approach based on fuzzy sets theory as a relevant methodological basis for assessing efficiency of risk mitigation and damage to health when planning and implementing activities aimed at ambient air protection. Application of this methodology allows assessing conditions of multi-component negative impacts producing multiple negative effects including direct damage done to human health. And here key parameters are assessed not as per point values but as per interval ones that are characterized with their belonging to a range of scaled parameters. Our research goal was to suggest methodical approaches to assessing efficiency of risk mitigation and damage to health when planning and implementing activities aimed at ambient air protection; the approaches were based on fuzzy sets theory. Results obtained via hygienic (field or calculated examinations of ambient air quality in settlements under exposure and beyond it) and epidemiologic (controlled medical and biological) research are taken as initial data for fuzzy modeling of multiple parameters ratios within "damage to health - mitigation efficiency" system. Principles applied for research design take into account key postulates of exposure assessment, "dose - effect" relationship for an influencing substance, a concept of exposure risk acceptability, peculiarities related to body reactions under combined aerogenic burdens, and plans for ambient air protection activities (including complex ones).

Comparing a list of substances that do actual damage to exposed population's health with a list of substances included into plans on aggregated emissions reduction allows assessing adequacy; determining to what extent damage to health is mitigated allows assessing whether activities aimed at ambient air protection are sufficient and effective.

Key words: damage to health, exposed population, ambient air contamination, mitigation, adverse effects, fuzzy sets theory, ambient air protection, adequacy, sufficiency, effectiveness.

(c) Zaitseva N.V., Zemlyanova M.A., May I.V., Alekseev V.B, Trusov P.V., Khrushcheva E.V., Savochkina A.A., 2020

Nina V. Zaitseva - Academician of the Russian Academy of Sciences, Doctor of Medical Sciences, Professor, Scientific Director (e-mail: znv@fcrisk.ru; tel.: +7 (342) 237-25-34; ORCID: https://orcid.org/0000-0002-4315-5307).

Marina A. Zemlyanova - Doctor of Medical Sciences, Chief Researcher acting as the Head of the Department for Biochemical and Cytogenetic Diagnostic Techniques (e-mail: zem@ffrisk.ru; tel.: +7 (342) 236-39-30; ORCID: http:// orcid.org/0000-0002-8013-9613).

Irina V. May - Doctor of Biological Sciences, Professor, Deputy Director responsible for research work (e-mail: may@fcrisk.ru; tel.: +7 (342) 237-25-47; ORCID: https://orcid.org/0000-0001-8997-5493).

Vadim B. Alekseev - Doctor of Medical Sciences, Director (e-mail: alekseev@fcrisk.ru; tel.: +7 (342) 236-32-70; ORCID: https://orcid.org/0000-0001-8997-5493).

Petr V. Trusov - Doctor of Physical and Mathematical Sciences, Professor, Head of Mathematic Modeling of Systems and Processes Department, Chief Researcher (e-mail: tpv@matmod.pstu.ac.ru; tel.: +7 (342) 239-16-07; ORCID: https://orcid.org/0000-0001-8997-5493).

Ekaterina V. Khrushcheva - Mathematician at Risk Management Techniques and Technologies Laboratory (e-mail: zem@fcrisk.ru; tel.: +7 (342) 238-33-37; ORCID: https://orcid.org/0000-0003-2107-8993).

Anna A. Savochkina - Senior lecturer at the Higher Mathematics Department (e-mail: aidas_76@mail.ru; tel.: +7 (342) 239-16-97; ORCID: https://orcid.org/0000-0003-2591-6632). 
Issues related to preserving demographic potential of our country as the basis for structural modernization of its economy ${ }^{1}$ are truly vital; existing substantial negative impacts on ambient air call for more precise assessments of actual damage to population health caused by violation of obligatory requirements fixed in the sanitary legislation ${ }^{2}$.

Industrial objects that emit huge amounts of dust and gas mixtures are often located within settlements or in close proximity to them; it often results in poorer living conditions and damage to population health. Such a situation is typical for many cities in the country, especially for those that are included into "Pure air" Federal project, an integral part of "Ecology" National project.

Several research works have revealed that negative impacts are often exerted by a set (an aggregate) of substances emitted by variable sources that differ in their power. A lot of people frequently have to live in a zone exposed to such emissions and there are multiple and various responses in their health caused by such exposure [1-6]. In such a situation it is crucial to assess a share contribution made by each source and each substance in aggregated negative effects produced on health taking into account hazards related to them. It is a substantial stage in assessing potential health risks and damage to health that is necessary for substantiating efficient programs for ambient air protection and activities aimed at mitigating such risks and damage $[7,8]$.

When assessing actual damage to health, it is advisable to preliminary assign activities performed by juridical persons and private en- trepreneurs into different categories; the focus should be on those economic entities that are located close to settlements and as their activities result in people living in such settlements being exposed to their emissions. This approach makes all the performed risk management activities more focused and targeted ${ }^{3}[9-11]$. A lot of researchers consider assessment of health risks caused by exposure to chemicals that pollute the environment a vital and integral stage in assessing damage to health. Such preliminary assessments allow accomplishing targeted medical and biological studies taking into account expected scientifically proven effects on organs and systems that are critical in terms of specific exposure ${ }^{4}[12-14]$.

Overall, a lot of research works are concentrating on searching and testing new approaches to assessing hazardous effects produced by ambient air contamination on health in order to provide more efficient management decisionmaking. Thus, Kliucininkas L., Velykiene D. (2009) examined abandoned industrial territories which had been previously exploited and suggested a procedure for calculating "emdavector', a complex index that comprised parameters of damage done to health and the environment due to economic activities [15].

Fabisiak et al. (2020) described a model based on risk assessment and clusterization of territories; the model showed how a burden of cardiovascular diseases occurred under exposure to certain environmental factors [16]. The model incorporated regression analysis and assessment of spatially distributed data on morbidity among population, ambient air contamination, and quantitative parameters of ex-

\footnotetext{
${ }^{1}$ The concept of the demographic policy in the Russian Federation up to 2025 / approved by the RF President Order on October 9, 2007 No. 1351 with alterations and supplements made on April 14, 2016 No. 669-r. Garant: portal with reference and legal information. Available at: https://base.garant.ru/191961/ 53f89421bbdaf741eb2d1ecc4ddb4c33/ (03.03.2020).

${ }^{2}$ On sanitary-epidemiologic welfare of the population: The federal Law issued on March 30, 1999 No. 52-FZ (last edited on July 26, 2019). Clause 57. Civil responsibility for causing damage due to violation of sanitary legislation. KonsultantPlus. Available at: http://www.consultant.ru/document/cons_doc_LAW_22481/9fba0cf13c7f6e7ee38079c2317f39d2a09220d0/ (03.03.2020).

${ }^{3}$ MG 5.1.0116-17 Methodical guidelines. Risk-oriented model for control and surveillance activities for providing sanitary-epidemiologic welfare. Classification of economic entities, types of activities and object under surveillance as per potential health risks for organizing scheduled control and surveillance activities / approved by the Federal Service for Surveillance over Consumer Rights Protection and Human Well-being on August 11, 2017, 16 p.

${ }^{4} \mathrm{G}$ 2.1.10.1920-04 Guide for assessing health risks under exposure to chemicals that pollute the environment. Moscow, The Federal Center for Sanitary and Epidemiologic Surveillance of the RF Public Healthcare Ministry, 2004, 143 p.
} 
posure available in literature. It was developed for making timely and well-substantiated political decisions. The authors stressed it was important to objectively assess burdens caused by specific contaminants and to determine population groups that were the most prone to risks; they also noted that analysis procedures required further development.

Substantial uncertainties that occur in analyzing and, even more so, in quantitative assessment of relations within the "contamination sources - environmental factors - population health - management" system are wellknown to practically all researchers in the sphere [17-19]. A lot of researchers state it is quite a complicated task to assess potential risks and actual damage given multiplicity and uncertainty of influencing factors and negative effects produced by them. Experts also understand that obtained results are not always consistent with an actual situation and they can lead to wrong managerial decisions and to additional inefficient costs [20-25]. Therefore, it is still vital to try and increase adequacy of assessments as an information base for decisionmaking; to achieve that, we require new approaches and analysis techniques.

Fuzzy sets theory (fuzzy logic) seems to have a capability to become a methodological basis for assessing efficiency of risks and damage mitigation when planning and implementing activities aimed at ambient air protection. The theory in its contemporary interpretation was developed by L. Zadeh [26-28]. Its main advantage, with relation to optimization and identification, is a formalized mathematical apparatus that allows working in uncertainty when there are no available data for applying theoretical-probabilistic techniques. The procedure allows [28]:

- working with fuzzy initial data, for example, values that constantly change over time (dynamic data series) as well as values which can't be set unambiguously;

- applying assessment criteria and comparisons that are not clearly formalized, such as "average", "high", "the greatest", "probable" etc.;

- performing qualitative assessments of initial data and output results and working with not only values but also reliability of data;
- quickly modeling complicated dynamic processes and comparing them with preset precision;

- assessing key parameters not with point values but with interval ones that are characterized with membership function (membership) within a range of scaled parameters.

All the above-mentioned advantages of the procedure sufficiently correspond to complicated tasks related to analyzing existing sanitaryepidemiologic situations in which damage is done to population health under exposure to multicomponent ambient air contamination $[29,30]$.

Given all that, we suggest an approach based on fuzzy sets theory as a relevant methodological base for assessing efficiency of risks and damage mitigation when planning and implementing activities aimed at ambient air protection. Application of the theory will allow assessing multi-component negative influences that produce multiple hazardous effects including damage to health. And key parameters here are assessed not with point values but with interval ones that are characterized with membership function within a range of scaled parameters. There isn't sufficient experience in applying fuzzy sets procedures for solving such tasks. Given that, it seemed appropriate to develop and test scientific-methodical approaches based on fuzzy sets; those approaches enabled assessing efficiency of preventing and eliminating actual damage when economic entities planned and implemented activities aimed at ambient air protection under multiplicity and uncertainty.

Our research goal was to suggest methodical approaches to assessing efficiency of health damage mitigation based on fuzzy sets theory when planning and implementing activities aimed at ambient air protection.

Data and methods. Our research object was a large industrial city with ambient air being heavily contaminated. To assess aerogenic exposure of the city population we took results of field observations over ambient air quality as our initial data. The observations were accomplished by certified laboratories belonging to Rosgidromet and Rospotrebnadzor's Center for Hygiene and Epidemiology. 
Instrumental data were supplemented with the results obtained via aggregated calculations of admixtures dispersion ${ }^{5}$. We specified zones in the city via creating a regular grid with its pitch being equal to $200 \times 200 \mathrm{~m}$. The regular grid covered the whole examined territory. We calculated ground concentrations at each node in the grid with linear inter- and extrapolation of data taken on the nearest posts for field observations.

We spotted out zones with different exposure as per criteria showing whether quality of ambient air in the city corresponded to the existing hygienic standards (average daily or average annual MPC) and/or reference concentrations (RfC chronic for chronic inhalation exposure $)^{6}$. To perform comparative assessments, we took a territory where chemicals contents in ambient air corresponded to the hygienic standards (or didn't exceed reference concentrations); the zone was conditionally denominated as "a zone beyond exposure". All the zones were comparable as per their socioeconomic, natural-geographic, and climatic parameters, as well as quality and availability of medical services rendered to population (types of medical services and procedures for rendering them in accordance with the existing standards for medical aid provision).

We quantitatively assessed aerogenic exposure of population taking into account ground concentrations of admixtures in each square of the regular grid. Exposure was given with average annual daily dose (ADDch, $\mathrm{mg} /(\mathrm{kg}$ *day) calculated in accordance with the section 6.4 .8 of the Guide 2.1.10.1920.04.

To establish whether there was damage done to health of people living in an exposed zone, we selected a representative sampling of people who were to have an individual profound medical examination. There was a comparative plan created for each person from exposed and non-exposed groups according to approaches and criteria given in details in methodical guidelines ${ }^{7}$; we performed diagnostics for each person including chemical and analytical research on biological media in order to determine xenobitoics and/or other technogenic admixtures; there were also general, biochemical, immunologic, and other laboratory examinations, and functional tests; people were examined by a medical expert, and a diagnosis was put in each particular case. We confirmed (or didn't confirm) any relation between detected health disorders and aerogenic exposure basing on the analysis of causeand-effect relations between exposure markers and markers of negative effects.

The next stage was aimed at determining a number of people with established diseases caused by aerogenic exposure to contaminants and involved creating an information database containing consistent (including a period of observation) data as per a disease category according to a chronic diseases that was revealed in a person for the $1^{\text {st }}$ time. And data on each person were correlated with a chronic average daily dose of each substance.

We analyzed our data array step by step applying fuzzy sets technique; the same approaches were applied to assess efficiency of activities aimed at ambient air protection (target reductions in emissions into the atmosphere from emission sources (tons per year), volumes and sources of funding, etc.) as per a criterion that described mitigation of actual damage to health of exposed population.

Results and discussion. We assessed efficiency of health damage mitigation when

\footnotetext{
${ }^{5}$ The Order by the RF Ministry of Natural Resources and The Environment issued on June 06, 2017 No. 273 "On Approving on the techniques for calculating dispersion of hazardous substances (contaminants) in ambient air". Garant: portal with reference and legal information. Available at: https:/www.garant.ru/products/ipo/prime/doc/71642906/ (03.03.2020); The Order by the RF Ministry of Natural Resources and The Environment issued on November 29, 2019 No. 813 "On Approving on the rules for performing aggregated calculations of ambient air contamination including their actualization" (registered in the RF Ministry of Justice on December 24, 2019 No. 56955). KonsultantPlus. Available at: http://www.consultant.ru/document/cons_doc_LAW_341489/(03.03.2020).

${ }^{6} \mathrm{G}$ 2.1.10.1920.04 Guide for assessing health risks under exposure to chemicals that pollute the environment. Moscow, The Federal Center for Sanitary and Epidemiologic Surveillance of the RF Public Healthcare Ministry, 2004, 143 p.

${ }^{7}$ MG 2.1.10.3165-14 The procedure for using results of medical and biological research in order to prove damage done to health due to negative impacts exerted by chemical environmental factors. Available at: https://files.stroyinf.ru/Data2/1/ $4293766 / 4293766706(04.03 .2020)$.
} 
planning ambient air protection and took it this assessment as an example to suggest and test an algorithm that included sequential phases.

The 1st stage involves estimating a total number of people with the same chronic disease that was first diagnosed in them over a period of observation separately as per each category $\left(\sum N^{Z}\right)$ and overall as per the whole aggregate of revealed diseases $\left(\sum N^{K}\right)$ correlated with chronic average daily dose of each substance that determined both each separate disease as per each revealed disease category $\left(A D V^{Z}\right)$ and the whole range of diseases over a 1-year observation period $\left(A D V_{i}^{K}\right)$. And here we took into account negative responses not only in accordance with critical organs and systems but also with comorbid states revealed via profound medical examinations.

The 2nd phase involved several steps. First of all, we ranked chronic average daily doses of contaminants under which, over a relevant observation period, experts revealed people with first diagnosed chronic diseases correlated with aerogenic exposure; then we determined a list of contaminants that were potentially hazardous in terms of damage to health. Doses were ranked as per potential hazards of damage to health according to a hazard scale that showed correlations between a chronic average daily dose of each substances (in fractions) and a number of people who could potentially suffer a damage to their health. There should be a permissibility creation for an actual chronic average daily dose of a substance (PDD, $\mathrm{mg} /(\mathrm{kg} *$ day) and a number of people correlated with it who could suffer a damage to their health. It is advisable to apply a limit value of "significant exposure" corresponding to an average daily (annual) dose of a substance under aerogenic exposure calculated from $0.5 \mathrm{MPC}$ $\left(0.5 M P C_{\text {a.a. }} \equiv 0.5 P D D_{\text {a.a. }} \equiv 0.5 P D D_{\text {a.d. }}\right)$. Daily long-term exposure to such a dose is correlated with one additional case of damage to health in a form of diagnosed grave chronic disease per 1 million of exposed people during any lifespan of the present and the following generations $\left(1 \times 10^{-6}\right)($ Table 1$)$.

A substance is considered to be potentially hazardous as per damage to health in case its potential hazard ranks 2 or higher; such substances are recommended to be included into plans for air protection activities.

The 3rd phase involves applying fuzzy sets theory in order to prove there was damage to health of exposed people in a form of additional chronic diseases that were first diagnosed over the analyzed period and were determined by long-term combined exposure to substances. Actual damage is scaled within a value range from 0 to 1 . A basic instrument required for implementing the procedure is a membership function $\mu(x)$ of a trapezoidal fuzzy number $x=\left(a_{1}, a_{2}, a_{3}, a_{4}\right)$; overall, the function is given as follows:

$$
\mu(x)=\left\{\begin{array}{ll}
0, & \text { if } x<a_{1}, \\
\frac{x-a_{1}}{a_{2}-a_{1}}, & \text { if } a_{1} \leq x<a_{2}, \\
\frac{1,}{\frac{x-a_{4}}{a_{3}-a_{4}},}, & \text { if } a_{2} \leq x \leq a_{3}, \\
0, & \text { if } x>a_{4} .
\end{array} .\right.
$$

Table 1

A hazard scale showing potential damage to health under aerogenic exposure to contaminants

\begin{tabular}{|l|c|c|c|c|c|c|}
\hline \multirow{2}{*}{ Scale parameter } & \multicolumn{5}{|c|}{ Potential hazard of damage to health: ranks } \\
\cline { 2 - 7 } & 1 & 2 & 3 & 4 & 5 \\
\cline { 2 - 7 } & \multicolumn{5}{|c|}{ Potential hazard of damage to health } \\
\cline { 2 - 7 } & Negligible & Low & Average & High & Extremely high \\
\hline $\begin{array}{l}\text { Fractions in PDDa.d. (or PDDa.a.) } \\
\text { for a year averaging }\end{array}$ & $(0 ; 0.25]$ & $(0.25 ; 0,5]$ & $(0,5 ; 1]$ & $(1 ; 5]$, & $(5 ;+\infty)$ \\
\hline $\begin{array}{l}\text { Number of people who can suffer } \\
\text { a damage to health correlated with } \\
\text { a certain number of population }\end{array}$ & $\left(0 ; 1 \cdot 10^{-8}\right]$ & $\begin{array}{c}\left(1 \cdot 10^{-8} ;\right. \\
\left.1 \cdot 10^{-6}\right]\end{array}$ & $\begin{array}{c}\left(1 \cdot 10^{-6} ;\right. \\
\left.1 \cdot 10^{-4}\right]\end{array}$ & $\begin{array}{c}\left(1 \cdot 10^{-4} ;\right. \\
\left.1 \cdot 10^{-3}\right],\end{array}$ & $\left(1 \cdot 10^{-3} ;+\infty\right)$ \\
\hline
\end{tabular}


Actual damage that corresponds to a revealed disease (disease category) for each person from an exposed group determined by a combined aerogenic exposure to chemicals is taken as a variable $r$; its value corresponds to a variable $x$ in the general formula (2) and a range of values $a$ that corresponds to a value of the variable $r$. The value of the variable $r$ is determined as per complex analysis performed on a system of parameters; these parameters are multiple chronic average daily doses of substances creating aggregated aerogenic exposure that is potentially hazardous as regards damage to health in a form of the whole aggregate of first diagnosed chronic diseases under long-term combined exposure.

To analyze a system of parameters, a chronic average daily dose of each substance included into the list is taken as a variable $\left(b_{i}\right)$ and its quantitative value given as $B_{i}$, is taken as a range of values. We should determine a membership of a chronic average daily dose of each substance (the variable $b_{i}$ ) within a certain range of values comprising chronic daily average doses $\left(B_{i k}\right)$. A value of membership function $\left(\mu_{k i}\right)$ for a chronic average daily dose of each substance within a range of values for chronic average daily doses that create aerogenic exposure and related damage to health of a certain number of people is determined as per the formula (2). Ranges of values for chronic average daily doses correspond to ranges on a hazard scale showing potential damage to health caused by aerogenic exposure (Table 1) with their boundaries being "fuzzy" $( \pm 20 \%)$ and probable overlapping between values belonging to neighboring ranges. Actual damage to health is differentiated as per 5 categories (Table 2).

It is obligatory to adjust plans for activities aimed at ambient air protection regarding contaminants that cause damage to health belonging to the $2^{\text {nd }}$ category ("low") and higher in order to provide efficient mitigation of damage to health of exposed population.

To quantitatively assess actual damage to health of exposed people, we gave a rank to a negative response (a disease category from $\mathrm{C} 00$ to R99 according to ICD10) (l) taking its gravity into account; responses were ranked within a range from 0 to 1 . A weight (frequency) of each disease category ranked as per its gravity in an aggregated negative response $\left(P_{l}\right)$ is determined as per Fishburn's rule (3) [27]:

$$
P_{l}=\frac{2(n-l+1)}{(n+1) n},
$$

where $P_{l}$ is a weight of a ranked disease category in an aggregated negative response; $n$ is an overall number of disease categories determined in an aggregated negative response caused by aerogenic exposure to all the substances; $l$ is a rank of a negative response (a disease category).

An established weight of each disease category $\left(P_{l}\right)$ applies to each substance that creates exposure and a related aggregated negative response $\left(P_{i}\right)$. A weight of actual damage as per each disease category (an observed weight) is determined according to a rule for transition from values for a weight of a chronic average daily dose of a substance to weights of actual damage to health determined by aerogenic exposure as per the following formula:

$$
P_{k}=\sum_{i} G_{i} \cdot \mu_{k i}, k=1,2,3,4,5,
$$

where $P_{k}$ is actual damage as per each disease category determined in an aggregated negative response caused by aggregated aerogenic exposure; $G_{i}$ is a weight of each substance that creates aerogenic exposure and a related aggregated negative response; $\mu_{k i}$ is a membership function for a chronic average daily dose of each substance within a relevant range on the scale showing values of chronic average daily doses of substances that do damage to health; $\mathrm{k}$ is a category of actual damage to health.

Aggregated actual damage to health $(r)$ is calculated basing on an established weight of actual damage as per each disease category revealed in an aggregated negative response and related to aggregated aerogenic exposure as per the following formula: 
Table 2

The scale showing ranges of values for chronic average daily doses of substances that determine damage to health of a certain number of people

\begin{tabular}{|c|c|c|c|}
\hline \multirow[b]{2}{*}{$\begin{array}{l}\text { A range of values } \\
\text { on the scale }\end{array}$} & \multirow{2}{*}{$\begin{array}{l}\text { A value of membership function for chronic average daily doses } \\
\text { of substances that cause damage to health }\left(A D V_{i}^{Z}\right) \text {, within ranges } \\
\text { of values on the scale, } \mathrm{mg} /(\mathrm{kg} * \text { day })\end{array}$} & \multicolumn{2}{|c|}{ Actual damage } \\
\hline & & $\begin{array}{c}\text { degree } \\
(\mathrm{k})\end{array}$ & $\begin{array}{l}\text { rank } \\
(\mathrm{Rg})\end{array}$ \\
\hline$B_{i 1} \in[0 ; 0.3 \mathrm{PDD}]$ & $\mu_{1}\left(\mathrm{ADV}_{\mathrm{i}}^{\mathrm{z}}\right)= \begin{cases}1, & \text { if } \quad 0 \leq \mathrm{ADV}_{\mathrm{i}}^{\mathrm{z}} \leq 0.2 \mathrm{PDD} \\
\frac{10}{\mathrm{PDD}}\left(0.2 \mathrm{PDD}-\mathrm{ADV}_{\mathrm{i}}^{\mathrm{z}}\right), & \text { if } \quad 0.2 \leq \mathrm{ADV}_{\mathrm{i}}^{\mathrm{z}} \leq 0.3\end{cases}$ & Negligible & 1 \\
\hline$B_{i 2} \in(0.2 \mathrm{PDD} ; 0.6 \mathrm{PDD}]$ & 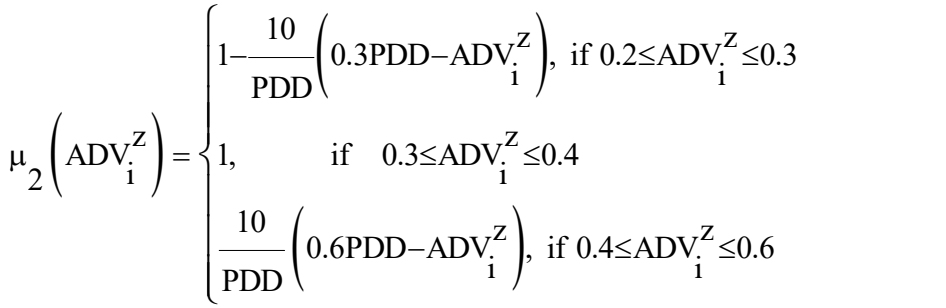 & Low & 2 \\
\hline$B_{i 3} \in(0.4 \mathrm{PDD} ; 1.2 \mathrm{PDD}]$ & $\mu_{3}\left(\mathrm{ADV}_{\mathrm{i}}^{\mathrm{Z}}\right)=\left\{\begin{array}{l}1-\frac{10}{\mathrm{PDD}}\left(0.67 \mathrm{PDD}-\mathrm{ADV}_{\mathrm{i}}^{\mathrm{Z}}\right), \text { if } 0.4 \leq \mathrm{ADV}_{\mathrm{i}}^{\mathrm{Z}} \leq 0.67 \\
1, \quad \text { if } \quad 0.67 \leq \mathrm{ADV}_{\mathrm{i}}^{\mathrm{Z}} \leq 0.94 \\
\frac{10}{\mathrm{PDD}}\left(1.2 \mathrm{PDD}-\mathrm{ADV}_{\mathrm{i}}^{\mathrm{Z}}\right), \text { if } 0.94 \leq \mathrm{ADV}_{\mathrm{i}}^{\mathrm{Z}} \leq 1.2\end{array}\right.$ & Average & 3 \\
\hline$B_{i 4} \in(0.8 \mathrm{PDD} ; 6 \mathrm{PDD}]$ & $\mu_{4}\left(\mathrm{ADV}_{\mathrm{i}}^{\mathrm{Z}}\right)=\left\{\begin{array}{l}1-\frac{10}{\mathrm{PDD}}\left(2.53 \mathrm{PDD}-\mathrm{ADV}_{\mathrm{i}}^{\mathrm{Z}}\right), \text { if } 0.8 \mathrm{PDD} \leq \mathrm{ADV}_{\mathrm{i}}^{\mathrm{Z}} \leq 2.53 \mathrm{PDD} \\
1, \quad \text { if } \quad 2.53 \mathrm{PDD} \leq \mathrm{ADV}_{\mathrm{i}}^{\mathrm{Z}} \leq 4.26 \mathrm{PDD} \\
\frac{10}{\mathrm{PDD}}\left(6 \mathrm{PDD}-\mathrm{ADV}_{\mathrm{i}}^{\mathrm{Z}}\right), \text { if } 4.26 \mathrm{PDD} \leq \mathrm{ADV}_{\mathrm{i}}^{\mathrm{Z}} \leq 6 \mathrm{PDD}\end{array}\right.$ & High & 4 \\
\hline$B_{i 5} \in(4 \mathrm{PDD} ;+\infty)$ & $\mu_{5}\left(\mathrm{ADV}_{\mathrm{i}}^{\mathrm{Z}}\right)=\left\{\begin{array}{l}\frac{10}{\mathrm{PDD}}\left(6 \mathrm{PDD}-\mathrm{ADV}_{\mathrm{i}}^{\mathrm{Z}}\right), \text { if } \quad 4 \mathrm{PDD} \leq \mathrm{ADV} \mathrm{i}_{\mathrm{i}}^{\mathrm{Z}} \leq 6 \mathrm{PDD} \\
1, \text { if } \quad \mathrm{ADV}_{\mathrm{i}}^{\mathrm{Z}} \geq 6 \mathrm{PDD}\end{array}\right.$ & $\begin{array}{l}\text { Extremely } \\
\text { high }\end{array}$ & 5 \\
\hline
\end{tabular}

Note: PDD stands for permissible daily dose.

$$
r=\sum_{k=1}^{5} \overline{r_{k}} \cdot P_{k}
$$

where $r$ is aggregated actual damage confirmed by an actual disease (a disease) determined by aerogenic chemical exposure to a set of substances; $\bar{r}_{k}$ is the middle of each range on the scale showing values of actual damage; $P_{k}$ is a weight of actual damage as per each disease category determined in an aggregated negative response related to aggregated aerogenic exposure.

The scale showing ranges of values for actual damage $(R)$ is given in Table 3 , and is graphically shown in Figure 2.

Table 3

The scale showing ranges of values for actual damage to health

\begin{tabular}{|l|c|c|}
\hline $\begin{array}{c}\text { Actual } \\
\text { damage }(\mathrm{k})\end{array}$ & $\begin{array}{c}\text { A range of } \\
\text { values for actual } \\
\text { damage }(\mathrm{R})\end{array}$ & $\begin{array}{c}\text { The middle of a } \\
\text { range of values } \\
\text { for actual damage }\end{array}$ \\
\hline Negligible & $R_{1} \in[0 ; 0.25]$ & 0.125 \\
\hline Low & $R_{2} \in(0.15 ; 0.45]$ & 0.3 \\
\hline Average & $R_{3} \in(0.35 ; 0.65]$ & 0.5 \\
\hline High & $R_{4} \in(0.55 ; 0.85]$ & 0.7 \\
\hline $\begin{array}{l}\text { Extremely } \\
\text { high }\end{array}$ & $R_{5} \in[0.75 ; 1]$ & 0.875 \\
\hline
\end{tabular}




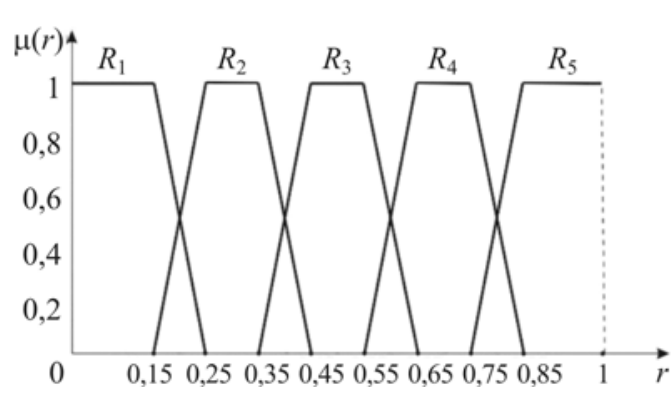

Figure 2. Ranges on the scale showing values of actual damage to health $(r)$

Actual damage to health $(R)$ is assessed basing on a determined value of membership function for actual damage $\left(\mu_{k}(r)\right)$ within ranges on the scale (Table 4).

Damage is considered to be proven provided that an established value of actual damage is within a range on the scale of values estimated as "low" and higher (rank 2 or higher). In order to achieve efficient mitigation of damage to population health in an exposed zone, it is necessary to draw up a list of contaminants that are subject to obligatory regula- tion as their rank of potential damage to health is 2 or higher.

A contribution made by each substance into actual damage to health is estimated as per the following formula:

$$
Q_{i}=\overline{r_{k}} \cdot G_{i} \cdot \mu_{k i} \cdot 100 \%
$$

where $Q_{i}$ is a contribution made by each substance into actual damage to health; $\overline{r_{k}}$ is the middle of each range on the scale showing actual damage; $G_{i}$ is a weight of each substance creating aerogenic exposure and a related aggregated negative response; $\mu_{k i}$ is a membership function for a chronic average daily dose of each substance within a relevant range on the scale showing values of average daily doses of substance that cause damage to health.

Actual damage as a negative effect as per a specific disease $(\Delta r)$ is determined for an exposed age group against the analogue nonexposed group.

Table 4

The scale showing actual damage to health

\begin{tabular}{|c|c|c|c|}
\hline \multirow[b]{2}{*}{$\begin{array}{l}\text { A range of values } \\
\text { on the scale }\end{array}$} & \multirow[b]{2}{*}{$\begin{array}{l}\text { Membership function for actual damage } \\
\text { within ranges on the scale }\end{array}$} & \multicolumn{2}{|c|}{ Actual damage } \\
\hline & & $\begin{array}{l}\text { degree } \\
(\mathrm{k})\end{array}$ & $\begin{array}{l}\text { rank } \\
(\mathrm{Rg})\end{array}$ \\
\hline$R_{1} \in[0 ; 0.25]$ & $\mu_{1}(r)=\left\{\begin{array}{lll}1, & \text { если } & 0 \leq r \leq 0.15 \\
10(0.25-r), & \text { если } & 0.15 \leq r \leq 0.25\end{array}\right.$ & Negligible & 1 \\
\hline$R_{2} \in(0.15 ; 0.45]$ & $\mu_{2}(r)=\left\{\begin{array}{lll}1-10(0.25-r), & \text { если } & 0.15 \leq r \leq 0.25 \\
1, & \text { если } & 0.25 \leq r \leq 0.35 \\
10(0.45-r), & \text { если } & 0.35 \leq r \leq 0.45\end{array}\right.$ & Low & 2 \\
\hline$R_{3} \in(0.35 ; 0.65]$ & $\mu_{3}(r)= \begin{cases}1-10(0.45-r), & \text { если } 0.35 \leq r \leq 0.45 \\
1, & \text { если } 0.45 \leq r \leq 0.55 \\
10(0.65-r), & \text { если } 0.55 \leq r \leq 0.65\end{cases}$ & Average & 3 \\
\hline$R_{4} \in(0.55 ; 0.85]$ & $\mu_{4}(r)= \begin{cases}1-10(0.65-r), & \text { если } 0.55 \leq r \leq 0.65 \\
1, & \text { если } 0.65 \leq r \leq 0.75 \\
10(0.85-r), & \text { если } 0.75 \leq r \leq 0.85\end{cases}$ & High & 4 \\
\hline$R_{5} \in[0.75 ; 1]$ & $\mu_{5}(r)=\left\{\begin{array}{l}1-10(0.85-r), \text { если } 0.75 \leq r \leq 0.85 \\
1, \quad \text { если } 0.85 \leq r \leq 1\end{array}\right.$ & Extremely high & 5 \\
\hline
\end{tabular}

Note: "если" = if. 
Table 5

Criteria for assessing adequacy and sufficiency of air protection activities

\begin{tabular}{|c|c|c|}
\hline $\begin{array}{c}\text { Criterion } \\
\text { denomination }\end{array}$ & Assessment criterion & Assessment \\
\hline \multirow{3}{*}{$\begin{array}{l}\text { Activities are } \\
\text { adequate as } \\
\text { regards the list } \\
\text { of contaminants }\end{array}$} & $\begin{array}{l}\text { The planned list of substances fully coincides with the adjusted list of } \\
\text { substances that are potentially hazardous in terms of damage to health and } \\
\text { recommended to be included into programs for ambient air protection }\end{array}$ & Adequate \\
\hline & $\begin{array}{l}\text { The planned list of substances partially (not sufficient or excessive) } \\
\text { coincides with the adjusted list of substances that are potentially haz- } \\
\text { ardous in terms of damage to health and recommended to be included } \\
\text { into programs for ambient air protection }\end{array}$ & $\begin{array}{l}\text { Partially } \\
\text { adequate }\end{array}$ \\
\hline & $\begin{array}{l}\text { The planned list of substances doesn't coincide at all with the adjusted list } \\
\text { of substances that are potentially hazardous in terms of damage to health } \\
\text { and recommended to be included into programs for ambient air protection }\end{array}$ & Not adequate \\
\hline \multirow{3}{*}{$\begin{array}{l}\text { Activities aimed } \\
\text { at achieving a } \\
\text { planned reduction } \\
\text { in contaminants } \\
\text { emissions are } \\
\text { sufficient }\end{array}$} & $\begin{array}{l}\text { Hazard of damage to health has reached its target level }(R g<2) \text { after } \\
\text { activities aimed at ambient air protection have been accomplished }\end{array}$ & Sufficient \\
\hline & $\begin{array}{l}\text { Hazard of damage to health has decreased but hasn't reached its target } \\
\text { level }(R g<2) \text { after activities aimed at ambient air protection have } \\
\text { been accomplished (they are not sufficient) }\end{array}$ & $\begin{array}{l}\text { Partially } \\
\text { sufficient }\end{array}$ \\
\hline & $\begin{array}{l}\text { Hazard of damage to health hasn't decreased after activities aimed at } \\
\text { ambient air protection have been accomplished }\end{array}$ & Not sufficient \\
\hline
\end{tabular}

An adjusted list of substances with their emissions being subject to obligatory regulations is drawn up on the basis of proven actual damage to health (a diagnosed disease) of a certain number of exposed people and an estimated contribution made by each substance into actual damage to health.

The $4^{\text {th }}$ phase involves assessing adequacy of air protection activities aimed at reducing actual emissions of contaminants into ambient air. The assessment is based on comparative analysis of the list of substances included into activity plans and a recommended list of substances that actually contribute into damage to health and are subject to obligatory regulation. Sufficiency of implemented activities is assessed basing on criterion comparative analysis of actual damage prior to and after those activities have been implemented (Table 5).

The list and emission volumes are to be adjusted only for those contaminants included into planned air protection activities for which efficiency of activities is estimated as being "partially adequate" and "not ade- quate" and/or as "partially sufficient" and "not sufficient".

In order to eliminate potential hazard of damage to health and achieve "sufficient" efficiency of planned ambient air protection, we should calculate a value of a recommended additional reduction in a chronic average daily dose for each substance included into the list of substances that are subject to obligatory regulation. The value is calculated as per the following formula (7):

$$
\triangle A D D_{i N}^{K}=\frac{\left(A D V_{i N}^{K}-0.5 P D D\right)}{A D D_{i N}^{K}} \cdot 100 \%,
$$

where $\triangle A D D_{i N}^{K}$ is an additional fraction of a chronic average daily dose of a substance that is recommended for eliminating potential hazard of damage to population health, \%; $A D V_{i N}^{K}$ is a chronic average daily dose of a substance that doesn't create any potential hazards of damage to health (as per any diseases out of the overall detected range) under combined exposure in unfavorable meteorological conditions, $\mathrm{mg} /(\mathrm{kg} *$ day). 
A necessary volume of emission into the atmosphere that provides an additional reduction in the aerogenic burden is calculated for each substance; such a reduction should be sufficient for mitigation of actual damage. This volume is calculated taking into account a contribution made by each economic entity into aggregated volume of contaminants emissions on the basis of finding a solution to an inverse task or calculations of dispersion.

Efficiency of damage mitigation is estimated on the basis of the re-estimation of actual damage as a negative effect as pre a specific disease category $\left(\Delta r_{N}\right)$ after activities aimed at ambient air protection have been implemented. Average value of actual damage as a negative effect determined by aerogenic exposure, as per aggregate of all the detected diseases, before $(c p \Delta r)$ and after $\left(c p \Delta r_{N}\right)$ activities aimed at ambient air protection have been implemented, is calculated as per the following formula:

$$
c p \Delta r=\frac{\sum_{K} \Delta r_{K}}{\mathrm{~K}},
$$

where $c p \Delta r$ is an average value of actual damage as a negative effect determined by aerogenic exposure, as per aggregate of all the detected diseases prior to (or after) activities aimed at ambient air protection have been implemented; $\Delta r_{K}-$ is a value of actual damage as a negative effect determined by aerogenic exposure as per aggregate of all the detected diseases prior to (or after) activities aimed at ambient air protection have been implemented; $K$ is the total quantity of all the detected disease categories.

Efficiency of activities aimed at reducing actual damage determined by aerogenic exposure after they have been implemented is estimated as per the following formula (9):

$$
\ni=\left(\frac{\mathrm{cp} \Delta \mathrm{r}-c p \Delta r_{N}}{\mathrm{cp} \Delta \mathrm{r}}\right) \cdot 100 \%,
$$

where $\ni$ is efficiency of activities aimed at reducing actual damage determined by aerogenic exposure after they have been implemented (prevented damage), $\% ; c p \Delta r$ is an average value of actual damage as a negative effect (as per aggregate of all the detected nosologies) determined by aerogenic exposure before activities aimed at ambient air protection have been implemented; $c p \Delta r_{N}$ is an average value of actual damage as a negative effect (as per aggregate of all the detected diseases) determined by aerogenic exposure after activities aimed at ambient air protection have been implemented.

Efficiency of activities aimed at preventing damage determined by aerogenic exposure after they have been implemented is assessed as per a scale given in Table 6 .

Table 6

A scale for assessing efficiency of planned (implemented) activities aimed at ambient air protection as per prevented damage to health

\begin{tabular}{|c|c|}
\hline Efficiency (E), \% & Degree of efficiency \\
\hline $0-20$ & unacceptable \\
\hline $20-40$ & low \\
\hline $40-60$ & acceptable \\
\hline $60-80$ & sufficient \\
\hline $80-100$ & high \\
\hline
\end{tabular}

Should the efficiency be absent or low, it is necessary to develop (plan) additional activities aimed at ambient air protection; should such activities turn out to be excessive, it is advisable to adjust them on order to make their efficiency "sufficient".

Suggested methodic approaches were tested on a territory with susbtantial aerogenic burden; the tests included assessing adequacy, sufficiency, and efficiency of a set of activities aimed at ambient air protection and planned to be implemented by major economic entities operating on the given territory.

All the above stated allowed us to come to the following conclusions:

- suggested approaches to applying elements of fuzzy sets theory for solving tasks related to assessing whether mitigation of 
damage to health is efficient allow assessing adequacy and sufficiency of planned or implemented activities aimed at ambient air protection under existing uncertainty. They can be treated as techniques that supplement and adjust results obtained via other research works within the "environmental factors - population health" system;

- it is vital to apply profound medical research on health disorders in order to prove there has been damage to health caused by combined aerogenic exposure as such research allows obtaining more precise estimations both at an individual level and a group one;
- when we compare a list of substances that actually contribute into damage to health of exposed population with a list of contaminants included into plans for reducing emissions into the atmosphere as per specific substances, it allows us to assess adequacy of ambient air protection; when we determine mitigation of damage to health when such activities are implemented, it helps assessing their efficiency and sufficiency.

Funding. The research was not granted any sponsor support.

Conflict of interests. The authors declare there is no any conflict of interests.

\section{References}

1. Klyuev N.N., Yakovenko L.M. «Dirty» cities in Russia: factors determining air pollution. Vestnik Rossiiskogo universiteta druzhby narodov. Seriya: Ekologiya i bezopasnost' zhiznedeyatel'nosti, 2018, vol. 26, no. 2, pp. 237-250 (in Russian). DOI: 10.22363/2313-2310-2018-26-2-237-250

2. Surzhikov V.D., Surzhikov D. V., Ibragimov S.S., Pananotti E.A. Air pollution as the factor of the influence on the life quality of the population. Byulleten' VSNTS SO RAMN, 2013, vol. 91, no. 3-2, pp. 135-139 (in Russian).

3. Tsimmerman V.I., Badmaeva S.E. The impact of the industry branches on the city air environment. Vestnik KrasGAU, 2015, no. 4, pp. 3-6 (in Russian).

4. Beelen R., Raaschou-Nielsen O., Stafoggia M., Andersen Z.J. Effects of long-term exposure to air pollution on natural-cause mortality: an analysis of 22 European cohorts within the multicentre ESCAPE project. Lancet, 2014, vol. 1, no. 383 (9919), pp. 785-795. DOI: 10.1016/S0140-6736(13)62158-3

5. Air pollution and child health: prescribing clean air. World Health Organization, 2018. Available at: https://www.who.int/ceh/publications/air-pollution-child-health/en/ (10.03.2020).

6. Götschi T., Heinrich J., Sunyer J., Künzli N. Long-term effects of ambient air pollution on lung function: a review. Epidemiology, 2008, vol. 19, no. 5, pp. 690-701. DOI: 10.1097/EDE.0b013e318181650f

7. Avaliani S.L., Revich B.A., Mishina A.L. The role of assessment of pro rata contribution of emissions from businesses outside the study area of the city, into various kinds of risks to public health. Zdorov'e naseleniya i sreda obitaniya, 2010, no. 11 (212), pp. 41-43 (in Russian).

8. Analiz riska zdorov'yu $\mathrm{v}$ strategii gosudarstvennogo sotsial'no-ekonomicheskogo razvitiya [Health risk analysis in the strategy for state social and economic development: a monograph]. In: G.G. Onishchenko, N.V. Zaitseva eds. Perm, PNIPU Publ., 2014, 738 p. (in Russian).

9. Goryaev D.V., Tikhonova I.V., Kir'yanov D.A. Industrial enterprises and health risk categories. Gigiena i sanitariya, 2017, vol. 96, no. 12, pp. 1155-1158 (in Russian). DOI: 10.18821/0016-99002017-96-12-1155-1158

10. Popova A.Yu., Zaitseva N.V., May I.V. experience of methodological support and practical implementation of the risk-oriented model of sanitary-epidemiological surveillance in 2014-2017. Gigiena i sanitariya, 2018, vol. 97, no. 1, pp. 5-9 (in Russian).

11. Kamaltdinov M.R., Kir'yanov D.A. Health risk assessment in violation of the legislation in the sphere of ensuring sanitary-epidemiological well-being of the population carried out to classify objects surveillance. Zdorov'e naseleniya $i$ sreda obitaniya, 2015, vol. 273, no. 12, pp. 8-11 (in Russian).

12. Kol'dibekova Yu.V., Zemlyanova M.A., Ignatova A.M., Tikhonova I.V., Markovich N.I., Chetverkina K.V., Ukhabov V.M. Assessment of the risk for health disorders in children who live in a territory of the zone of exposure to production of metallurgical aluminum. Gigiena i sanitariya, 2019, vol. 98, no. 2, pp. 135-141 (in Russian). DOI: 10.18821/0016-9900-2019-98-2-135-141 
13. Onishchenko G.G., Novikov S.M., Rakhmanin Yu.A., Avaliani S.L., Bushtueva K.A. Osnovy otsenki riska dlya zdorov'ya naseleniya pri vozdeistvii khimicheskikh veshchestv, zagryaznyayushch ikh okruzhayushchuyu sredu [Assessing risks of health disorders in children living in a zone exposed to metallurgic alumina production]. In: Yu.A. Rakhmanina, G.G. Onishchenko eds. Moscow, NII ECh i GOS Publ., 2002, 408 p. (in Russian).

14. Mamyrbaev A.A.., Sakebaeva L.D., Sabyrakhmetova V.M., Karashova G.I., Shayakhmetova K.N., Umarova G.A. Assessment of risk of non-carcinogenic effects due to the pollution of atmospheric air in residential areas of Uralsk city. Meditsinskii zhurnal Zapadnogo Kazakhstana, 2016, vol. 49, no. 1, pp. 82-88 (in Russian).

15. Kliucininkas L., Velykiene D. Environmental health damage factors assessment in brownfield redevelopment. Proceedings WIT Transactions on Biomedicine and Health, 2009, vol. 14, pp. 179-186. DOI: $10.2495 /$ EHR090181

16. Fabisiak J.P., Jackson E.M., Brink L.L., Presto A.A. A risk-based model to assess environmental justice and coronary heart disease burden from traffic-related air pollutants. Environ Health, 2020, vol. 16, no. 19 (1), pp. 34. DOI: 10.1186/s12940-020-00584-z

17. Lucas R.M, McMichael A.J. Association or Causation: evaluating links between «environment and disease». Bulletin of the World Health Organization: the International Journal of Public Health, 2005, vol. 83, no. 10, pp. 792-795.

18. Hill A.B. The Environment and Disease: Association or Causation? Proceedings of the Royal Society of Medicine, 1965, vol. 58, pp. 295-300.

19. Science for Environment Policy. The precautionary principle: decision-making under uncertainty. Available at: https://ec.europa.eu/environment/integration/research/newsalert/pdf/precautionary_principle_decision_making_under_uncertainty_FB18_en.pdf (20.03.2020).

20. Simankov V.S., Buchatskaya V.V., Teploukhov S.V. Approach to the accounting for initial information uncertainty in system researches. Vestnik Adygeiskogo gosudarstvennogo universiteta. Seriya 4: Estestvenno-matematicheskie i tekhnicheskie nauki, 2017, vol. 3, no. 206, pp. 100-107 (in Russian).

21. Shoina I.I. Risk appraisal in conditions of uncertainty. Nauchnyi vestnik MGTU GA, 2006, no. 106, pp. 165-169 (in Russian).

22. Kuz'min E.A. The problem of uncertainty as a scientific category. Strategicheskie resheniya $i$ risk-menedzhment, 2014, no. 3, pp. 90-100 (in Russian).

23. Kleyn S.V., Zaitseva N.V., May I.V. Questions form of evidence of harm to public health in terms of ecological trouble. Okhrana okruzhayushchei sredy i prirodopol'zovanie, 2013, no. 2, pp. 28-32 (in Russian).

24. Zaitseva N.V., Zemlyanova M.A., Luzhetskii K.P., Kleyn S.V. Scientific justification of the exposure and effect biomarkers in terms of proving health impact when identifying environmentallydetermined unacceptable risk. Vestnik Permskogo universiteta. Seriya Biologiya, 2016, no. 4, pp. 374-378 (in Russian).

25. Bondarenko P.V., Fokina E.A., Trukhlyaeva A.A. Application of the theory of fuzzy sets for assessment of the quality of life population of the region. Fundamental'nye issledovaniya, 2015, no. 11-5, pp. 967-971 (in Russian).

26. Zadeh L., Bellman R. Decision-making in a fuzzy environment. Management Science, 1970, vol. 17, no. 4, pp. 41-164. DOI:10.1287/mnsc.17.4.B141

27. Zade L.A. Ponyatie lingvisticheskoi peremennoi i ego primenenie k prinyatiyu priblizhennykh reshenii [A concept of linguistic variable and its application in getting approximate solutions]. In: N.N. Moiseev, S.A. Orlovskii eds. Moscow, Mir Publ., 1976, 165 p. (in Russian).

28. Diligenskii N.V., Dymova L.G., Sevast'yanov P.V. Nechetkoe modelirovanie i mnogokriterial'naya optimizatsiya proizvodstvennykh sistem $\mathrm{v}$ usloviyakh neopredelennosti: tekhnologiya, ekonomika, ekologiya [Fuzzy modeling and multi-criteria optimization of industrial systems under uncertainty: technology, economy, and ecology]. Available at: http://os.x-pdf.ru/20ekonomika/ 411551-1-diligenskiy-dimova-sevastyanov-nechetkoe-modelirovanie-mnogokriter.php (04.03.2020) (in Russian). 
29. Tah J.H.M., Carr V. A proposal for construction project risk assessment using fuzzy logic. Construction Management \& Economics, 2000, vol. 18, no. 4, pp. 491-500. DOI: 10.1080/01446190050024905

30. Kochubei N.A. Modeli prinyatiya reshenii na osnove nechetkikh mnozhestv [Models for decision-making based on fuzzy sets]. Ekonomicheskii analiz: teoriya i praktika, 2010, vol. 17, no. 182, pp. 63-67 (in Russian).

Zaitseva N.V., Zemlyanova M.A., May I.V., Alekseev V.B, Trusov P.V., Khrushcheva E.V., Savochkina A.A. Efficiency of health risk mitigation: complex assessment based on fuzzy sets theory and applied in planning activities aimed at ambient air protection. Health Risk Analysis, 2020, no. 1, pp. 25-37. DOI: 10.21668/health.risk/2020.1.03.eng

Received: 18.02 .2020

Accepted: 24.03.2020

Published: 30.03.2020 